\title{
NURSE-LED INTERVENTIONS TO PROMOTE HOSPITALIZED PATIENTS' ADHERENCE TO HAND HYGIENE: NARRATIVE REVIEW
}

Intervenções de Enfermagem para a promoção da adesão à higienização das mãos em pessoas hospitalizadas: revisão narrativa da literatura

Intervenciones de enfermería para promover la adhesión a la higiene de manos en personas hospitalizadas: revisión narrativa de la literatura

\author{
Ana Nunes*, Joana Carrasquinho**, Paulo Santos-Costa***, Luciene Braga****, Beatriz Serambeque*****, \\ Pedro Parreira******, Anabela Oliveira*******
}

\begin{abstract}
Background: during the hospital admission, nurses play a fundamental role in the adherence to hand hygiene (HH) measures by patients and their families, enhancing the quality and safety of care. Objective: synthesize the latest scientific evidence regarding nurse-led interventions focused on hospitalized patients' adherence to $\mathrm{HH}$ and its impact on preventing Healthcare-Associated Infections (HAls). Methodology: following the PICOD mnemonic, a narrative review was conducted in MEDLINE (via PubMed), CINAHL (via EBSCO), and Cochrane Library. Two independent reviewers analyzed the relevance of the studies, extracted and synthesized data. Results: seven studies were included for review, published between 2016 and 2018. Three central themes emerged: i) nurse-led interventions that promote patients' adherence to $\mathrm{HH}$; ii) patients' $\mathrm{HH}$ adherence and HAls prevention; iii) the importance of personcentered nursing care in this scope. Conclusion: isolated interventions do not lead to adequate behavioural changes. Although educational interventions are the most common actions used by nurses, visual cues, distribution of informational material, provision of $\mathrm{HH}$ material, and creation of specific moments for $\mathrm{HH}$ are complementary strategies that enhance the efficiency and quality of the intervention.
\end{abstract}

Keywords: hand hygiene; nurses; patient-centered care

* RN, Nursing School of Coimbra, Health Sciences Research Unit: Nursing (UICISA: E) https://orcid.org/0000-0002-4455-7615 Contribuição no artigo: Data collection, Data analysis and interpretation, Drafting of the article, Critical revision of the article

** RN, Nursing School of Coimbra, Health Sciences Research Unit: Nursing (UICISA: E) htiences Research Unit: Nursing (Urcid.org/0000-0002-1606-0687

$\frac{\text { https://orcid.org/0000-0002-1606-0687 }}{\text { Contribuição no artigo: Data collection, Data }}$ - Contribuição no artigo: Data collection, Data
analysis and interpretation, Drafting of the article, Critical revision of the article

*** PhD Student, Nursing School of Coimbra, Health Sciences Research Unit: Nursing (UICISA: E) - https://orcid.org/0000-0003-0761-6548 Contribuição no artigo: Data collection, Dat Contribuiça analysis and interpretation, Drafting of the
article, Critical revision of the article

**** PhD, Medicine and Nursing department, Federal University of Viçosa https://orcid.org/0000-0002-2297-395X Contribuição no artigo: Study conception and design, Data analysis and interpretation, Critical revision of the article

***** MSc, Nursing School of Coimbra, Health Sciences Research Unit: Nursing (UICISA: E) http://orcid.org/0000-0002-3634-859X Contribuição no artigo: Data analysis and interpretation, Critical revision of the article ****** PhD, Nursing School of Coimbra, Health Sciences Research Unit: Nursing (UICISA: E) https://orcid.org/0000-0002-3880-6590 Contribuição no artigo: Study conception and

design, Critical revision of the article Sciences Research Unit: Nursing (UICISA: E) Sciences Research Unit: Nursing (UICISA: E) https://orcid.org/0000-0002-8231-8279 Contribuição no artigo: Study conception and design, Critical revision of the article

\section{Como referenciar:}

Nunes, A., Carrasquinho, J., Santos-Costa, P., Braga, L., Serambeque, B., Pereira, P., \& Oliveira, A., (2021). Nurse-led interventions to promote hospitalized patients' hospitalized patients adherence to hand Investigação \& Inovação em Saúde, 4(1), 75-85 Investigação \& Inovação em Saúde, 4(1),
https://doi.org/10.37914/riis.v4i1.122

Recebido para publicação em: 16/03/2021 Aceite para publicação:15/06/2021

\section{RESUMO}

Enquadramento: durante o período de internamento hospitalar, os enfermeiros desempenham um papel fundamental na adesão às medidas de higienização das mãos (HM) por parte das pessoas doentes e seus familiares, potenciando a qualidade e segurança dos cuidados. Objetivo: sintetizar a evidência científica mais recente respeitante às intervenções de enfermagem focadas na promoção da adesão à HM em pessoas hospitalizadas e o seu impacte na prevenção de Infeções Associadas aos Cuidados de Saúde (IACS). Metodologia: através da mnemónica PICOD, conduziu-se uma revisão narrativa da literatura na MEDLINE (PubMed), CINAHL (EBSCO) e Cochrane Library. Dois revisores independentes analisaram a relevância dos estudos, extraíram e sintetizaram os dados. Resultados: sete estudos foram incluídos na revisão final, publicados entre 2016 e 2018. Emergiram três temas centrais: intervenções de enfermagem focadas na promoção da adesão à HM por pessoas hospitalizadas; ii) adesão das pessoas à HM e prevenção de IACS; iii) a importância dos cuidados de enfermagem centrados na pessoa neste âmbito temático. Conclusão: intervenções isoladas não fomentam alterações comportamentais adequadas. Ainda que as intervenções educacionais sejam as mais recorrentemente utilizadas por enfermeiros, lembretes visuais, material informativo, distribuição de material e criação de momentos específicos para a HM são estratégias complementares que potenciam a eficiência e qualidade da intervenção.

Palavras chave: higiene das mãos; enfermeiras e enfermeiros; assistência centrada no paciente

\section{RESUMEN}

Marco contextual: durante la estancia hospitalaria, el enfermero juega un papel fundamental en el cumplimiento de las medidas de higiene de manos (HM) por parte de los enfermos y sus familiares, mejorando la calidad y seguridad de la atención. Objetivo: sintetizar la evidencia científica más reciente sobre las intervenciones dirigidas por enfermeros centradas en la adherencia de los pacientes hospitalizados a la HM y su impacto en la prevención de las Infecciones Asociadas a la Atención Sanitária (IAAS). Metodología: utilizando el mnemónico PICOD, se realizó una revisión narrativa de la literatura en MEDLINE (PubMed), CINAHL (EBSCO) y Cochrane Library. Dos revisores independientes analizaron la relevancia de los estudios, extrajeron y sintetizaron los datos. Resultados: se incluyeron siete estudios para revisión, publicados entre 2016 y 2018. Surgieron tres temas centrales: i) intervenciones dirigidas por enfermeras que promueven la adherencia de los pacientes a la HM; ii) adherencia de los pacientes a la HM y prevención de las IAAS; iii) la importancia del cuidado de enfermería centrado en la persona en este ámbito. Conclusión: las intervenciones aisladas no conducen a cambios de comportamiento adecuados. Si bien las intervenciones educativas son las acciones más utilizadas en enfermería, las señales visuales, material informativo, la provisión de material y la creación de momentos específicos para HM son estrategias complementarias que mejoran la eficiencia y calidad de la intervención.

Palabras clave: higiene de las manos; enfermeras y enfermeros; atención dirigida al paciente 


\section{INTRODUCTION}

Knowledge societies in the 21st century face the paradox of health decision making - while people are increasingly dared to make healthier choices, they are not being sufficiently prepared and supported by health professionals to make them (Kickbusch et al., 2013). The empowerment and accountability of people for their health is a significant challenge for nursing, particularly regarding the importance of HealthcareAssociated Infections (HAls) prevention and control.

The importance of involving patients and their families in HAls prevention and control has been established for years. Increasing discussions around safety culture highlight the need to create a collaborative environment between health team members, administrators, patients, and their families to overcome health barriers and strive for quality and efficient care (Joint Commission, 2009). However, despite significant advances in recent years, the risk of developing HAls in healthcare institutions is yet to be overcome and therefore requires effective preventive measures. One crucial challenge in this scope is related to the recurrent transmission of pathogenic microorganisms through the hands of health professionals and hospitalized patients (crosscontamination)(Istenes et al., 2013). Equally relevant, hospitalized patients are likely to be exposed to pathogenic microorganisms in clinical settings through direct contact with contaminated devices and surfaces, commonly known as self-contamination (Istenes et al., 2013). Hand hygiene $(\mathrm{HH})$ is considered one of the simplest and most effective practices in reducing HAls, thereby contributing to the reduction of patient morbidity and mortality. The importance of $\mathrm{HH}$ among hospitalized patients dates to the $1980 \mathrm{~s}$, with the development of international quality improvement projects and dissemination through scientific publications. Although $\mathrm{HH}$ standards traditionally focus on health professionals (Graveto, Rebola, et al., 2018; Graveto, Santos, et al., 2018), it is essential to include and educate hospitalized patients and their families about the relevance of this practice, establishing them as active agents in HAls prevention (Landers et al., 2012; World Health Organization, 2009). Nurses' patient education plays a fundamental role in $\mathrm{HH}$ adherence, and the contributions of current technological aids associated with simple and innovative strategies cannot be overlooked (Park \& Seale, 2017). Nurses' patient education can more easily impact health outcomes if they include a definition of terms, examples, illustrations, reminders or suggestions (Kickbusch et al., 2013). Thus, we proposed to conduct a narrative review with two main goals: i) to synthesize the latest scientific evidence regarding nurse-led interventions focused on hospitalized patients' adherence to $\mathrm{HH}$; ii) discuss the impact of the found nurse-led interventions on the prevention of HAls.

\section{METHODOLOGICAL REVIEW PROCEDURES}

To address the review question "Can nurse-led interventions enhance hospitalized patients' adherence to hand hygiene and its impact on the prevention of HAls?", a narrative literature review was conducted. To delineate the inclusion and exclusion criteria, the Participants, Interventions, Comparator, Outcome, Design (PICOD) mnemonic was used (Table 1). 
Nurse-led interventions to promote hospitalized patients' adherence to hand hygiene: narrative review

Table 1

Inclusion and exclusion criteria for selected studies following the PI[C]OD mnemonic

\begin{tabular}{|c|c|c|}
\hline & Inclusion criteria & Exclusion criteria \\
\hline $\mathrm{P}$ (articpants) & $\begin{array}{l}\text { Hospitalised patients with } 18 \text { years or } \\
\text { more of age. }\end{array}$ & $\begin{array}{l}\text { Patients followed in ambulatory care, clinics or other } \\
\text { settings that do not require full hospital admission. }\end{array}$ \\
\hline I(ntervention) & $\begin{array}{l}\text { Nurse-led interventions focused on } \\
\text { patients' adherence to } \mathrm{HH} \text {. }\end{array}$ & $\begin{array}{l}\text { Studies focused on interventions to promote health } \\
\text { professionals' adherence to } \mathrm{HH} \text {. }\end{array}$ \\
\hline C(omparator) & All types of comparators will be accepte & \\
\hline O(utcomes) & $\begin{array}{l}\text { - Studies focused on patients' } \\
\text { adherence rates related to } \mathrm{HH} \text {; } \\
\text { - Studies focused on the impact of } \\
\text { patients' adherence to } \mathrm{HH} \text { in HAls } \\
\text { incidence or prevalence rates; } \\
\text { - Studies focused on the impact of } \\
\text { patients' adherence to } \mathrm{HH} \text { in the } \\
\text { contamination of their hands by } \\
\text { pathogenic microorganisms. }\end{array}$ & $\begin{array}{l}\text { - Studies that explore patients' beliefs about } \mathrm{HH} \text {; } \\
\text { - Studies focused on nurses perceptions of } \\
\text { empowering patients to perform } \mathrm{HH} \text {. }\end{array}$ \\
\hline D(esign) & $\begin{array}{l}\text { Primary studies (qualitative or } \\
\text { quantitative). }\end{array}$ & $\begin{array}{l}\text { Systematic reviews of the literature, } \\
\text { governmental/institutional reports, or opinion } \\
\text { pieces. }\end{array}$ \\
\hline
\end{tabular}

The search strategy included published studies and was composed of three steps: i) restricted search in MEDLINE (via PubMed) to identify articles on this topic, followed by the analysis of text words in titles and abstracts and index terms used to describe these articles; ii) a second search using all keywords and index terms identified in the included databases; iii) the reference list of all articles and reports found in the search were analyzed to identify supplementary studies.

Boolean logic was used with search terms, adapting the strategy to each of the included databases. The natural language terms used were: nurs*; hand hygiene; hand washing; handwashing; hand disinfection; patient; and inpatient. Descriptors were also used according to each specific database, namely Medical Subject Headings (hand hygiene; hand disinfection; nurses; patients) and CINAHL Subject
Headings (handwashing; nurses; patients). The search strategy was adapted to each of the included databases. Regarding the search strategy and study identification, the following online databases were searched: MEDLINE (via PubMed), CINAHL (via EBSCO), and the Cochrane Library. Studies written in English, Spanish, French, and Portuguese were considered for inclusion in this review, published between January 1st, 2016 and December 31st, 2018. The final database search was conducted on April 26th, 2019.

To assort study relevance, two independent reviewers confronted the information provided in the title and abstract with the inclusion criteria delineated. Every time the reviewers had doubts about the relevance of a study, the study was included for full-text analysis. Two reviewers independently revised the full-text version of the articles to comprehend if the inclusion criteria were met. Divergences between the reviewers 
were decided through dialogue with a third reviewer. An identical approach was employed to the studies identified after the analysis of the reference lists. Data extraction was conducted by two independent reviewers using an instrument previously created by the authors. The instrument was designed to recover data consistent with this review's question and objectives. This literature review followed the steps recommended in the Preferred Reporting Items for Systematic Reviews and Meta-Analyzes checklist (Moher et al., 2009).

\section{RESULTS}

The search identified 691 potentially relevant studies. Of these, 202 were excluded for being duplicates. The remaining 489 articles were screened by title and abstract. Of these, 16 articles were included for fulltext analysis by two independent reviewers. Overall, 9 studies were excluded, due to the type of participants $(n=5)$, intervention $(n=1)$ and outcome $(n=3)$ not matching the inclusion criteria. Therefore, seven studies were included for data extraction and synthesis (Table 2).

Table 2

Characteristics and main results of the studies included for review

\begin{tabular}{|c|c|c|c|c|}
\hline $\begin{array}{c}\text { Authors and } \\
\text { Country }\end{array}$ & $\begin{array}{l}\text { Design and } \\
\text { participants }\end{array}$ & $\begin{array}{c}\text { Nurses' } \\
\text { interventions }\end{array}$ & Study outcomes & Main results \\
\hline $\begin{array}{l}\text { Ong and } \\
\text { collaborators } \\
\text { (2017) } \\
\text { Country: } \\
\text { Singapure }\end{array}$ & $\begin{array}{l}\text { Pre and post } \\
\text { comparative } \\
\text { study (with an } \\
\text { audit). } \\
\text { Participants. } 54\end{array}$ & $\begin{array}{l}\text { - Creation of a } \\
\text { reference guide } \\
\text { for nurses to } \\
\text { provide patient } \\
\text { education about } \\
\mathrm{HH} \text {; } \\
\text { - Creation of } \\
\text { standard } \\
\text { education record } \\
\text { about each } \\
\text { patient adherence } \\
\text { to HH; } \\
\text { - Development of } \\
\text { a leaflet for } \\
\text { patients regarding } \\
\text { Methicillin- } \\
\text { resistant } \\
\text { Staphylococcus } \\
\text { aureus (MRSA) } \\
\text { infection. }\end{array}$ & Patients' HH knowledge. & $\begin{array}{l}\text { - Patients' knowledge } \\
\text { regarding the importance of } \\
\text { HH increased by } 48.1 \% \text { after } \\
\text { the study; } \\
\text { - Nurses' documentation } \\
\text { regarding patient education } \\
\text { and adherence to } \\
\text { increased by } 44.5 \% \text {. } \\
\text { - Patients' comprehension of } \\
\text { MRSA infection causes } \\
\text { increased by } 36.1 \% \text {. }\end{array}$ \\
\hline $\begin{array}{l}\text { Haverstick } \\
\text { and } \\
\text { collaborators } \\
\text { (2017) } \\
\text { Country: USA }\end{array}$ & $\begin{array}{l}\text { Pre and post } \\
\text { comparative } \\
\text { study } \\
\text { Participants: } 38\end{array}$ & $\begin{array}{l}\text { - Distribution of } \\
\text { antiseptic gel } \\
\text { packages or } \\
\text { disinfectant wipes } \\
\text { to patients; } \\
\text { - Distribution and } \\
\text { reading of the } \\
\text { leaflet "The } \\
\text { importance of } \\
\mathrm{HH}^{\prime} \text {. }\end{array}$ & $\begin{array}{l}\text { HAls rates caused by } \\
\text { Vancomycin-resistant } \\
\text { enterococci, Clostridium } \\
\text { Difficile or MRSA. }\end{array}$ & $\begin{array}{l}\text { - Decrease of } 70 \% \text { in } \\
\text { infections caused by VRE; } \\
\text { - Decrease of } 63 \% \text { in } \\
\text { infections caused by MRSA } \\
\text { infections; } \\
\text { - Increase of } 31 \% \text { in } \\
\text { Clostridium } \\
\text { infections. }\end{array}$ \\
\hline
\end{tabular}




\begin{tabular}{|c|c|c|c|c|}
\hline & & $\begin{array}{l}\text { - Constant prompt } \\
\text { for patient } \mathrm{HH} \text {. }\end{array}$ & & \\
\hline $\begin{array}{l}\text { Rai and } \\
\text { collaborators } \\
\text { (2017a) } \\
\text { Country: USA }\end{array}$ & $\begin{array}{l}\text { Randomised } \\
\text { Controlled Trial } \\
\text { Participants: } 54 \\
\text { (control group: } \\
\text { 26; Experimental } \\
\text { group: } 28 \text { ) }\end{array}$ & 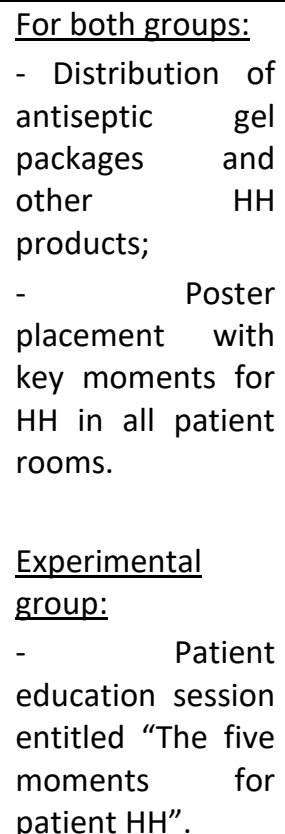 & $\begin{array}{l}\text { - Patient hand sanitizer use; } \\
\text { - Patients frequency of } \\
\text { performance of HH. }\end{array}$ & $\begin{array}{l}\text { - The experimental group } \\
\text { used antiseptic gel more } \\
\text { recurrently than the control } \\
\text { group; } \\
\text { - The experimental group } \\
\text { performed HH more often } \\
\text { than the control group when } \\
\text { health professionals entered } \\
\text { their room (although only } \\
\text { statistically significant in the } \\
\text { first day after the } \\
\text { intervention } \\
\text { implementation). }\end{array}$ \\
\hline $\begin{array}{l}\text { Sunkesula and } \\
\text { collaborators } \\
(2015) \\
\text { Country: USA }\end{array}$ & $\begin{array}{l}\text { Randomised } \\
\text { Controlled Trial } \\
\text { Participants: } 95\end{array}$ & $\begin{array}{l}\text { - Patient } \\
\text { education session } \\
\text { entitled "The four } \\
\text { moments for } \\
\text { patient HH"; } \\
\text { - Poster } \\
\text { placement with } \\
\text { key moments for } \\
\text { patient HH; } \\
\text { - Distribution of } \\
\text { packages of } \\
\text { antiseptic gel; } \\
\text { - Recurrent } \\
\text { prompt for } \\
\text { patient HH with } \\
\text { water and soap. }\end{array}$ & $\begin{array}{l}\text { Patient } \mathrm{HH} \text { performance } \\
\text { before eating and when } \\
\text { entering or exiting the } \\
\text { room. }\end{array}$ & $\begin{array}{l}\text { - } 34 \% \text { of the participants in } \\
\text { the control group had their } \\
\text { hands contaminated with } \\
\text { pathogens. In the } \\
\text { experimental group, only } 2 \% \\
\text { of the participants had their } \\
\text { hands contaminated. } \\
\text { - The most found } \\
\text { microorganism was MRSA } \\
\text { (in both groups). } \\
\text { - Fluoroquinolone-resistant } \\
\text { Gram-negative bacilli were } \\
\text { found in the hands of } 9 \% \text { of } \\
\text { the participants in the } \\
\text { control group (none in the } \\
\text { experimental group). } \\
\text {-Vancomycin-resistant } \\
\text { Enterococci were not found } \\
\text { in this study. }\end{array}$ \\
\hline $\begin{array}{l}\text { Pokrywka and } \\
\text { colleagues } \\
\text { (2017) } \\
\text { Country: USA }\end{array}$ & $\begin{array}{l}\text { Quasi- } \\
\text { experimental } \\
\text { study, with two } \\
\text { phases. } \\
\text { Phase 1: } \\
97 \text { (before) and } \\
291 \text { patients } \\
\text { (after) the } \\
\text { intervention } \\
\text { Phase 2: hospital } \\
\text { implementation } \\
\text { (495 beds) }\end{array}$ & $\begin{array}{l}\text { - Nurses training } \\
\text { session regarding } \\
\text { the importance of } \\
\mathrm{HH} \text {; } \\
\text { - Reminder for } \\
\text { nurses to } \\
\text { encourage/assist } \\
\text { patients to } \\
\text { perform HH; } \\
\text { - education, with } \\
\text { the distribution of } \\
\text { a manual for } \\
\text { patient admission; }\end{array}$ & $\begin{array}{l}\text { - Number of Patient } \mathrm{HH} \\
\text { opportunities provided by } \\
\text { staff; } \\
\text { - Average number of times } \\
\text { HH performed by patients } \\
\text { per day; } \\
\text { - Hospital-onset of } \\
\text { Clostridium difficile } \\
\text { infection. }\end{array}$ & $\begin{array}{l}\text { Phase 1: } \\
\text { - The number of } \\
\text { opportunities for HH, } \\
\text { assisted by nurses, increased } \\
\text { in 43.3\%; } \\
\text { - Patients' HH compliance } \\
\text { increased in three key } \\
\text { moments: before touching } \\
\text { wounds or medical devices } \\
\text { (131.2\%); before and after } \\
\text { family visits (74.2\%); after } \\
\text { any clinical procedure } \\
(73.7 \%) ;\end{array}$ \\
\hline
\end{tabular}




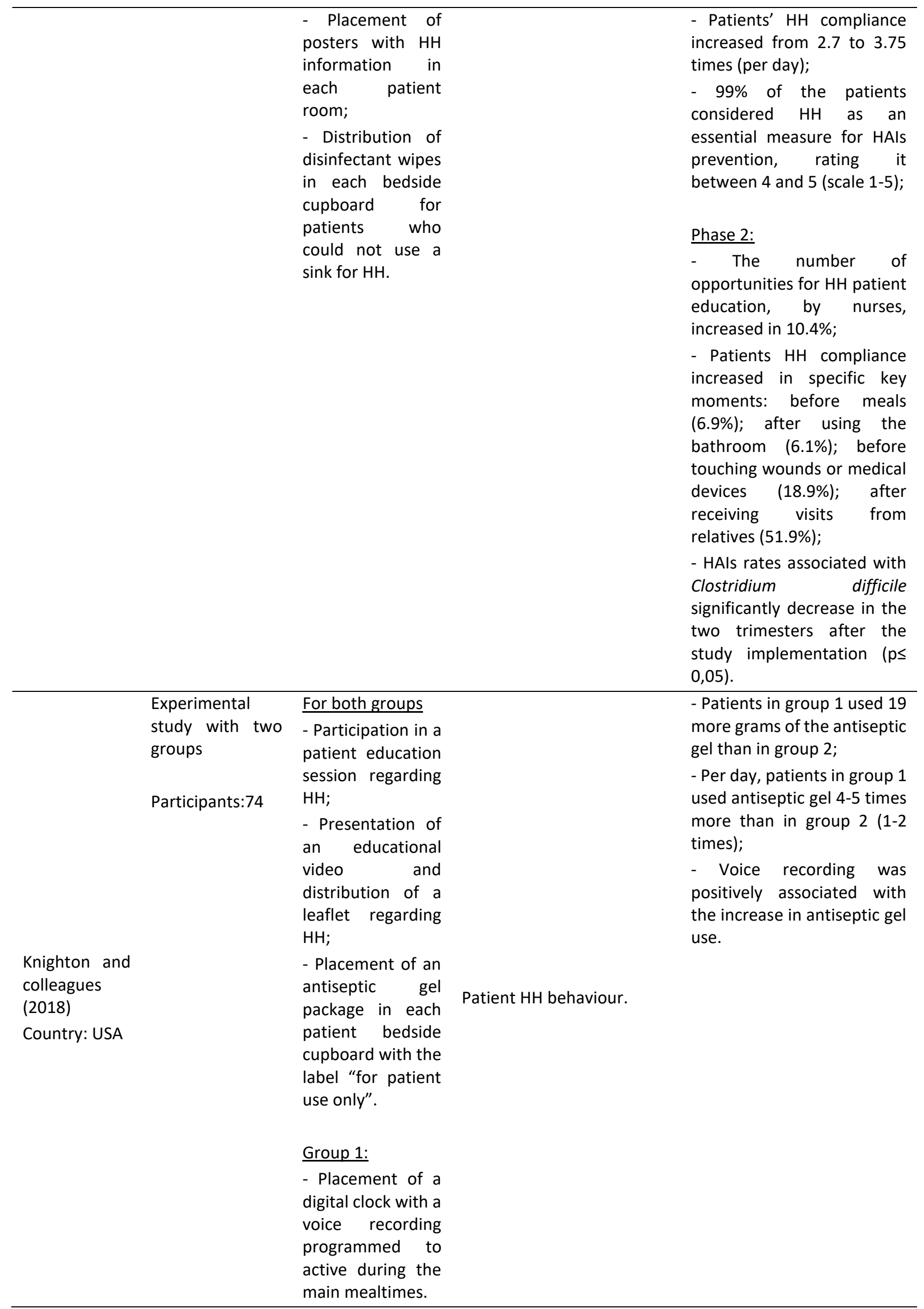




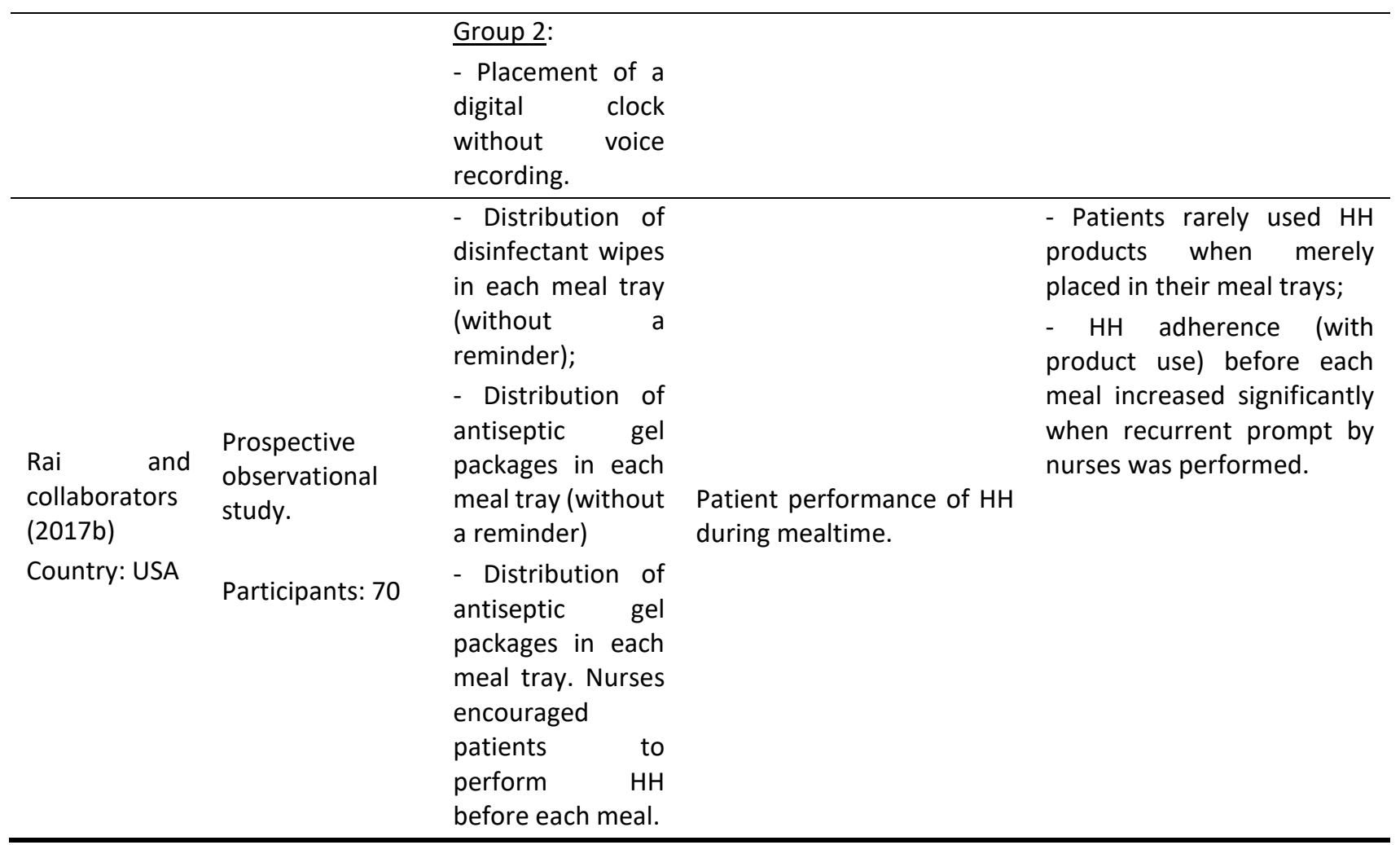

\section{DISCUSSION}

The included studies addressed nurse-led interventions that promote patients' $\mathrm{HH}$ adherence. Patient education on the importance of $\mathrm{HH}$ stands out as the most chosen nurse-led intervention, with a significant impact on patients' knowledge in this domain. As an example, after the implementation of an educational nurse-led intervention (with distribution of an informative leaflet), Ong and colleagues (2017) identified a $48.1 \%$ increase in patient awareness of the importance of $\mathrm{HH}$ and a $36.1 \%$ increase in their knowledge of MRSA infections. This result was also obtained by other study authors who implemented traditional nurse-led educational interventions (Pokrywka et al., 2017; Rai et al., 2017a). In the study by Pokrywka and colleagues (2017), 99\% of the participants highlighted the importance of $\mathrm{HH}$ in the prevention of HAls and increased the daily frequency of $\mathrm{HH}$ from 2.7 times to 3.75 times. This positive trend continued after the institutional implementation of the study, with significant increases in patients' adherence to $\mathrm{HH}$, especially after receiving visits (51.9\%). Similarly, Rai and associates (2017a) identified an increased frequency of $\mathrm{HH}$, with greater consumption of antiseptic gel in the experimental group, especially at specific times like the entry of health professionals into their room. However, this result was only statistically significant for the first day after the implementation of the nurse-led intervention (Rai et al., 2017a).

Such results reinforce the need to constantly promote patients' adherence to $\mathrm{HH}$ during their hospital admission, especially during mealtimes. For example, Rai and colleagues (2017b) found that the mere distribution of $\mathrm{HH}$ products like disinfectant wipes or antiseptic gel did not correlate into greater patient adherence. In their study, patients who used $\mathrm{HH}$ products more often were the ones who were constantly prompt by nurses. Likewise, Knighton and 
associates (2018) found that through a pre-established voice recording during mealtimes, patients increased their adherence to $\mathrm{HH}$. This result indicates the potential of technology as a tool that helps nurses to recurrently remind patients of the need for $\mathrm{HH}$.

\section{Impact in the prevention of HAls}

The nurse-led intervention implemented by Sunkesula and collaborators (2015) was comprised of an education session for the promotion of $\mathrm{HH}$, placement of posters in patients' rooms, frequent encouragement of $\mathrm{HH}$ and distribution of antiseptic gel packages contributed to the reduction of contamination of the hands of the hospitalised person. After its implementation, $2 \%$ of the patients in the experimental group had their hands contaminated with MRSA versus $30 \%$ in the control group. Fluoroquinolone-resistant gram-negative bacilli were also found in the hands of $4 \%$ of the control group participants, whereas in the hands of the experimental group participants this pathogen was not found (Sunkesula et al., 2015).

In another study, after the implementation of a similar nurse-led intervention, that also included the provision of disinfectant wipes to patients, the incidence of HAls caused by Clostridium difficile decreased (Pokrywka et al., 2017). Haverstick and colleagues (2017), identified that an increase in patients' $\mathrm{HH}$ adherence was associated with a $70 \%$ decrease in the incidence of HAls caused by VRE and $63 \%$ by MRSA. However, the authors identified a $31 \%$ increase in HAls caused by Clostridium difficile, which could be attributed to the incorrect use of specific $\mathrm{HH}$ products such as disinfectant wipes. This result highlights the need to select $\mathrm{HH}$ products not only based on patients' preferences and capabilities but also based on current known outbreaks of multiresistant microorganisms in hospital settings.

\section{Promotion of patients' self-care}

Despite its recognised importance in the prevention of HAls, some hospitalized patients do not have the opportunity to perform $\mathrm{HH}$ due to their functional status and dependence (Haverstick et al., 2017). Moreover, patients' lack of dexterity or cognitive abilities were also identified as key factors that influence HH adherence (Pokrywka et al., 2017). According to Okada and collaborators (Okada et al., 2016), the degree of contamination of the hands of hospitalised patients is higher in individuals with physical limitations. Since dependent people have difficulty in mobilising and performing basic needs (e.g., showering or using the bathroom), nurses and healthcare assistants often replace them in their selfcare. Such scenarios reduce the opportunities to prompt patients to perform $\mathrm{HH}$ actively (Pokrywka et al., 2017).

Nurses must be aware of the suitability of $\mathrm{HH}$ products for each patient's health condition and preferences (Knighton et al., 2018). Certain materials may not be compatible with the person's motor and cognitive abilities, such as the use of disinfectant wipes and antiseptic gel packs. As an example, in one study, patients who select antiseptic gel packs stated that it is easier, quicker, and more convenient to use (Rai et al., 2017b). However, patients who prefer disinfectant wipes indicated that they could be used more than once in a single moment (e.g., meal) and have a mechanical action that increases $\mathrm{HH}$ efficiency when hands are visibly soiled (Rai et al., 2017b). 
Promoting hospitalised patients' $\mathrm{HH}$ encompasses their capacity and active role in contributing to the prevention of HAls and, consequently, to their safety when using health services (Seale et al., 2016). Given that nurses are the health professionals who have continuous contact with admitted patients, they are in a privileged position to promote HH (Okada et al., 2016). However, several challenges can hinder nurses' role within this scope, such as: the lack of time to encourage and assist patients; nursing ratios; architectural barriers (e.g., existence of bathrooms in each patient room or the adaptability of washbasins for wheelchair use); and availability of individual $\mathrm{HH}$ products for patient use due budget constraints (Srigley et al., 2016).

The found nurse-led interventions and strategies considered most effective for the promotion of $\mathrm{HH}$ in hospitalised patients are similar to the WHO recommendations for health professionals' adherence to HH (Kickbusch et al., 2013; World Health Organization, 2009). These educational interventions must include visual clues, the provision of $\mathrm{HH}$ products and conduction of active vigilance and verbal reinforcement (Haverstick et al., 2017; Pokrywka et al., 2017; Srigley et al., 2016). Nurse-led interventions can contribute to patients' health literacy, empowering them to make the most appropriate health decisions and improve their self-care skills (Kickbusch et al., 2013).

As limitations of this review, the significant heterogeneity of studies found concerning their objectives, methodological design, and sample, may have limited data analysis, comparison, and synthesis. Thus, we believe that future experimental studies with larger samples are required, focusing on a set of pre- defined outcomes in light of recent international recommendations for $\mathrm{HH}$. In the same line of thought, the inclusion of studies published in English, Portuguese and Spanish may have limited the number of results that met the inclusion criteria. Also, studies accessible through other international databases could add contributions to the research question. Future literature reviews must address the weaknesses acknowledged to develop more comprehensive research in this scope.

\section{CONCLUSION}

Through this review, it was possible to identify nurseled interventions that positively contribute to patients' adherence to $\mathrm{HH}$. Out-of-the-way nurse-led interventions are not enough to generate behavioural changes. Although simple educational sessions are essential to increase patient knowledge about the importance of $\mathrm{HH}$ as a form of HAls prevention, the included studies in this review show that multimodal interventions prove to be more effective in medium to long-term modifications. To achieve better patient outcomes in this scope, nurses can combine traditional educational sessions with other resources and strategies such as distributing $\mathrm{HH}$ products, handing out information leaflets or placing posters in patient rooms. Moreover, nurse-led educational intervention must be phased, creating recurrent opportunities for patient engagement and encouragement in respect to $\mathrm{HH}$.

Equally important, the included studies also highlighted the impact of such nurse-led interventions on HAls prevention, with fewer studies analysing the positive impact of such interventions in the contamination of patients' hands with pathogenic 
microorganisms. The importance of person-centered care when encouraging patients' self-care in this domain was a recurrent concern of the included study authors. Nurses must be aware of patients' preferences when choosing appropriate HH products, as well as their capabilities and functional status to create effective opportunities for $\mathrm{HH}$.

\section{ACKNOWLEDGEMENTS}

The authors would like to thank the support of the Health Sciences Research Unit: Nursing (UICISA: E), hosted by the Nursing School of Coimbra (ESEnfC). The author PSC (SFRH/BD/136487/2018) would like to thank the Portuguese National Funding Agency for Science, Research and Technology (FCT) for the financial support granted through the 2018 Ph.D. Scholarship program.

\section{FUNDING}

This study is part of the project Transfer of technological innovation to nurses' practices: contributions to infection prevention, funded by the European Regional Development Fund - ERDF, through the PORTUGAL 2020 Operational Competitiveness and Internationalization Program.

\section{REFERENCES}

Graveto, J., Rebola, R. I. F., Fernandes, E. A., \& Costa, P. J. D. S. (2018). Hand hygiene: Nurses' adherence after training. Revista Brasileira De Enfermagem, 71(3), 1189-1193. https://doi.org/10.1590/0034-7167-20170239

Graveto, J., Santos, C., Costa, P. S., Fernandes, E., Alarico, S., Osório, N., Albano, H., \& Oliveira, V. (2018). Hand hygiene management among nurses: Collective health challenges. Revista Brasileira De Enfermagem, 71(suppl 1), 562-567. https://doi.org/10.1590/00347167-2017-0538

Haverstick, S., Goodrich, C., Freeman, R., James, S., Kullar, R., \& Ahrens, M. (2017). Patients' Hand Washing and Reducing Hospital-Acquired Infection. Critical Care Nurse, 37(3), e1-e8. https://doi.org/10.4037/ccn2017694

Istenes, N., Bingham, J., Hazelett, S., Fleming, E., \& Kirk, J. (2013). Patients' potential role in the transmission of health care-associated infections: Prevalence of contamination with bacterial pathogens and patient attitudes toward hand hygiene. American Journal of Infection Control, 41(9), 793-798. https://doi.org/10.1016/j.ajic.2012.11.012

Joint Commission (Ed.). (2009). Patients as partners in the infection prevention and control process. Joint Commission Resources.

Kickbusch, I., Pelikan, J. M., Apfel, F., Tsouros, A. D., \& World Health Organization (Eds.). (2013). Health literacy: The solid facts. World Health Organization Regional Office for Europe. Retrieved from https://apps.who.int/iris/bitstream/handle/10665/12 8703/e96854.pdf

Knighton, S. C., Dolansky, M., Donskey, C., Warner, C., Rai, H., \& Higgins, P. A. (2018). Use of a verbal electronic audio reminder with a patient hand hygiene bundle to increase independent patient hand hygiene practices of older adults in an acute care setting. American Journal of Infection Control, 46(6), 610-616. https://doi.org/10.1016/j.ajic.2018.01.005

Landers, T., Abusalem, S., Coty, M.-B., \& Bingham, J. (2012). Patient-centered hand hygiene: The next step in infection prevention. American Journal of Infection Control, 40(4 Suppl 1), S11-17. https://doi.org/10.1016/j.ajic.2012.02.006

Moher, D., Liberati, A., Tetzlaff, J., Altman, D. G., \& PRISMA Group. (2009). Preferred reporting items for systematic reviews and meta-analyses: The PRISMA statement. PLoS Medicine, 6(7), e1000097. https://doi.org/10.1371/journal.pmed.1000097

Okada, J., Yamamizu, Y., \& Fukai, K. (2016). Effectiveness of hand hygiene depends on the patient's health condition and care environment. Japan Journal of Nursing Science: JJNS, 13(4), 413-423. https://doi.org/10.1111/jjns.12122

Ong, A. Y. J., Tan, J., Yeo, H. L., \& Goh, M. L. (2017). Patient-centred hand hygiene information in orthopaedics units: An evidence-based 
implementation project. International Journal of Evidence-Based Healthcare, 15(1), 22-29. https://doi.org/10.1097/XEB.0000000000000094

Park, J., \& Seale, H. (2017). Examining the online approaches used by hospitals in Sydney, Australia to inform patients about healthcare associated infections and infection prevention strategies. BMC Infectious Diseases, 17(1), 788. https://doi.org/10.1186/s12879017-2899-2

Pokrywka, M., Buraczewski, M., Frank, D., Dixon, H., Ferrelli, J., Shutt, K., \& Yassin, M. (2017). Can improving patient hand hygiene impact Clostridium difficile infection events at an academic medical center? American Journal of Infection Control, 45(9), 959-963. https://doi.org/10.1016/j.ajic.2017.06.019

Rai, H., Knighton, S., Zabarsky, T. F., \& Donskey, C. J. (2017a). A randomized trial to determine the impact of a 5 moments for patient hand hygiene educational intervention on patient hand hygiene. American Journal of Infection Control, 45(5), 551-553. https://doi.org/10.1016/j.ajic.2016.12.022

Rai, H., Knighton, S., Zabarsky, T. F., \& Donskey, C. J. (2017b). Comparison of ethanol hand sanitizer versus moist towelette packets for mealtime patient hand hygiene. American Journal of Infection Control, 45(9), 1033-1034.

https://doi.org/10.1016/j.ajic.2017.03.018
Seale, H., Chughtai, A. A., Kaur, R., Phillipson, L., Novytska, Y., \& Travaglia, J. (2016). Empowering patients in the hospital as a new approach to reducing the burden of health care-associated infections: The attitudes of hospital health care workers. American Journal of Infection Control, 44(3), 263-268. https://doi.org/10.1016/j.ajic.2015.10.003

Srigley, J. A., Furness, C. D., \& Gardam, M. (2016). Interventions to improve patient hand hygiene: A systematic review. The Journal of Hospital Infection, 94(1), 23-29. https://doi.org/10.1016/j.jhin.2016.04.018

Sunkesula, V. C. K., Knighton, S., Zabarsky, T. F., Kundrapu, S., Higgins, P. A., \& Donskey, C. J. (2015). Four Moments for Patient Hand Hygiene: A PatientCentered, Provider-Facilitated Model to Improve Patient Hand Hygiene. Infection Control and Hospital Epidemiology, 36(8), 986-989. https://doi.org/10.1017/ice.2015.78

World Health Organization (Ed.). (2009). WHO guidelines on hand hygiene in health care: First global patient safety challenge: clean care is safer care. World Health Organization, Patient Safety. Retrived from https://apps.who.int/iris/rest/bitstreams/52455/retri eve 
